Jurnal Kependudukan Indonesia | Vol. 10 No. 1 Juni 2015 | 11-26

JURNAL KEPENDUDUKAN INDONESIA

p-ISSN : 1907-2902 (Print)

e-ISSN : 2502-8537 (Online)

\title{
ENVIRONMENTAL, DEMOGRAPHIC, AND SOCIO-ECONOMIC CORRELATES OF ACCESS TO IMPROVED SANITATION: EMPIRICAL EVIDENCE FROM PAPUAAND WEST PAPUA PROVINCES
}

\section{(LINGKUNGAN, DEMOGRAFI, SOSIO-EKONOMI YANG BERKORELASI DENGAN AKSES KE FASILITAS SANITASI YANG LAYAK: BUKTI EMPIRIS DARI PROVINSI PAPUA DAN PROVINSI PAPUA BARAT)}

\author{
Sri Irianti ${ }^{1}$ and Puguh Prasetyoputra ${ }^{2 *}$ \\ ${ }^{1}$ National Institute of Health Research and Development, Ministry of Health, Republic of Indonesia \\ ${ }^{2}$ Research Center for Population, Indonesian Institute of Sciences \\ * Corresponding author: pprasetyoputra@gmail.com
}

\begin{abstract}
Abstrak
Provinsi Papua dan Papua Barat adalah dua di antara provinsi-provinsi di Indonesia yang masih kekurangan akses terhadap sanitasi yang layak. Oleh karena itu tulisan ini menyajikan hasil analisis faktor-faktor yang berhubungan dengan akses sanitasi meliputi lingkungan, demografi dan sosio-ekonomi di kedua provinsi tersebut. Data dari Multiple Indicator Cluster Survey (MICS) 2011 dipakai untuk menentukan faktorfaktor lingkungan, demografi dan sosio-ekonomi yang berkorelasi dengan akses ke fasilitas sanitasi yang layak pada tingkat rumah tangga. Model-model regresi probit diaplikasikan pada data tersebut. Hasil analisis menunjukkan bahwa kecamatan, tempat tinggal, jenis dan lokasi sumber air rumah tangga, jumlah anggota rumah tangga, umur dan pendidikan kepala rumah tangga, dan tingkat kekayaan rumah tangga merupakan faktor-faktor yang berkorelasi secara signifikan dengan akses sanitasi layak. Hasil dari analisis memperkuat hasil penelitian sebelumnya dan lebih penting lagi, dapat dipakai sebagai bahan pembuatan kebijakan terutama di Provinsi Papua dan Provinsi Papua Barat.
\end{abstract}

Kata Kunci: Sanitasi Dasar, MICS, Regresi Probit, Efek Marginal, Disparitas

\section{INTRODUCTION}

Access to safe water and sanitation is key determinant in development outcomes across the life course (The Lancet, 2014), as lack of which is responsible for many

\begin{abstract}
Papua and West Papua provinces are two of many lagging provinces in Indonesia in terms of access to adequate sanitation. Hence, this paper aims to reveal determinants of access to improved sanitation by investigating the environmental, demographic, and socio-economic correlation in both provinces. Data from the 2011 Multiple Indicator Cluster Survey (MICS) were used to determine the demographic and socio-economic correlates of households' access to improved sanitation facilities. Probit regression models were fitted to the data. The results suggest that district, place or residence, type and location of household water source, household size, age of household head, education of household head, and household wealth have significant correlation with access to improved sanitation. These corroborate previous findings and more importantly, it can be used to inform policy makers in Indonesia especially in Papua and West Papua Provinces.
\end{abstract}

Keywords: Basic Sanitation, MICS, Probit Regression, Marginal Effect, Inequality

episodes of diarrhoeal diseases and its subsequent mortalities (Fuller, Westphal, Kenney, \& Eisenberg, 2015; Prüss-Ustün et al., 2014). Therefore, access to water and sanitation is a human right (Gleick, 1998; 
United Nations, 2010), as it significantly contribute to the development of human health.

It was reported that the world's target of Millennium Development Goal (MDG) for drinking water was met (WHO/UNICEF JMP, 2014). However, having access to improved water does not guarantee one from contracting water related diseases for several reasons. First, sufficient quantity of water is needed to flush faeces or to wash hands after defecation. Second, there is a possibility of recontamination by unhygienic practices (Freeman et al., 2014; Rufener, Mäusezahl, Mosler, \& Weingartner, 2010). Third, lack of access to improved sanitation also increases the risk of contamination of drinking-water sources (Bain et al., 2014).

Globally, 2.5 billion people did not have access to an improved sanitation facility in 2012, and if the current trends coverage increase continues, then the MDG sanitation target will not be achieved (WHO/UNICEF JMP, 2014). In 2013, two of five Indonesian households still did not have access to improved sanitation facility, with varying coverage across provinces (NIHRD, 2013) owing to slow progress during the past two decades (Haryanto \& Sutomo, 2012). The Government of Indonesia (GoI) targets acceleration of increasing coverage to achieve universal access to drinking-water and sanitation by 2019 through the Presidential Regulation No. 185 in 2014 (Government of Indonesia, 2014). Inequalities in access to improved sanitation related to location and socio-economic status of household in Indonesia (Prasetyoputra \& Irianti, 2013) and increased pressure from increasing population size and density (Mara, Lane, Scott, \& Trouba, 2010) also can be obstacles in achieving this target.

Many provinces in Eastern Indonesia are still laggards in development despite considerable progress (Booth, 2004; Hill, Resosudarmo, \& Vidyattama, 2008). This is also true for sanitation coverage where Eastern Indonesia provinces are among the lowest (Patunru, 2015). This paper takes Papua and West Papua provinces as examples. Access to improved sanitation facility in Papua and West Papua in 2013 was still behind national average of $59.8 \%$ (30.5\% and 54.9\%) (NIHRD, 2013). However, little is known about disparities of access to improved sanitation within those provinces. Studying the factors behind access to improved sanitation facilities will help directing intervention to increase access and alleviate disparities. Therefore, using the 2011 Indonesia Multiple Cluster
Indicator Survey (henceforth 2011 Indonesia MICS), this paper addressed the demographic and socioeconomic correlates of access to improved sanitation facility. In doing so, bivariate and multivariate probit regression models were fitted to the data.

Globally, this study is not the first to investigate the demographic and socio-economic correlates of access to improved sanitation facility (see Blakely, Hales, Kieft, Wilson, and Woodward (2005); Prasetyoputra and Irianti (2013); Gross and Günther (2014)). However, our contribution is threefold: first, an underutilised regression model in Indonesia is used. Second, this study focuses on two, relatively lagged in development provinces, Papua and West Papua. Third, this study takes advantage of the internationally standardised MICS dataset. Four, this study also explored the demographic dimension of access to improved sanitation facility.

Cross-sectional data from the 2011 Indonesia MICS from Indonesia collected in 2011 were used for analysing the socio-demographic and economic correlates of access to improved sanitation facility in Papua Province and West Papua Province. The sample and survey methodology are explained elsewhere (Statistics Indonesia, 2013a, 2013b, 2014). The dataset has been de-identified by the UNICEF and Statistics Indonesia to preserve anonymity of respondents. Ethical review was not sought as such.

The 2011 Indonesia MICS included responses from 3000 households drawn from Papua Province and 2913 households drawn from West Papua Province. The surveys collected information on water and sanitation facilities, housing characteristics, ownership of assets, and socio-demographic characteristics of household head which are the main interests this study. A total of 182 households $(6.07 \%)$ were excluded from the Papua dataset and 231 households (7.93\%) from the West Papua dataset using list wise deletion (Dong \& Peng, 2013).

The only dependent variable in this study is access to improved sanitation facilities. It is defined as facilities that prevent contact of human excreta with human (WHO/UNICEF JMP, 2006). The Joint Monitoring Programme (JMP) between the World Health Organization (WHO) and the United Nations Children Fund proposed a classification of sanitation ladder based on health outcomes for the purpose of monitoring (WHO/UNICEF JMP, 2006, 2008). 


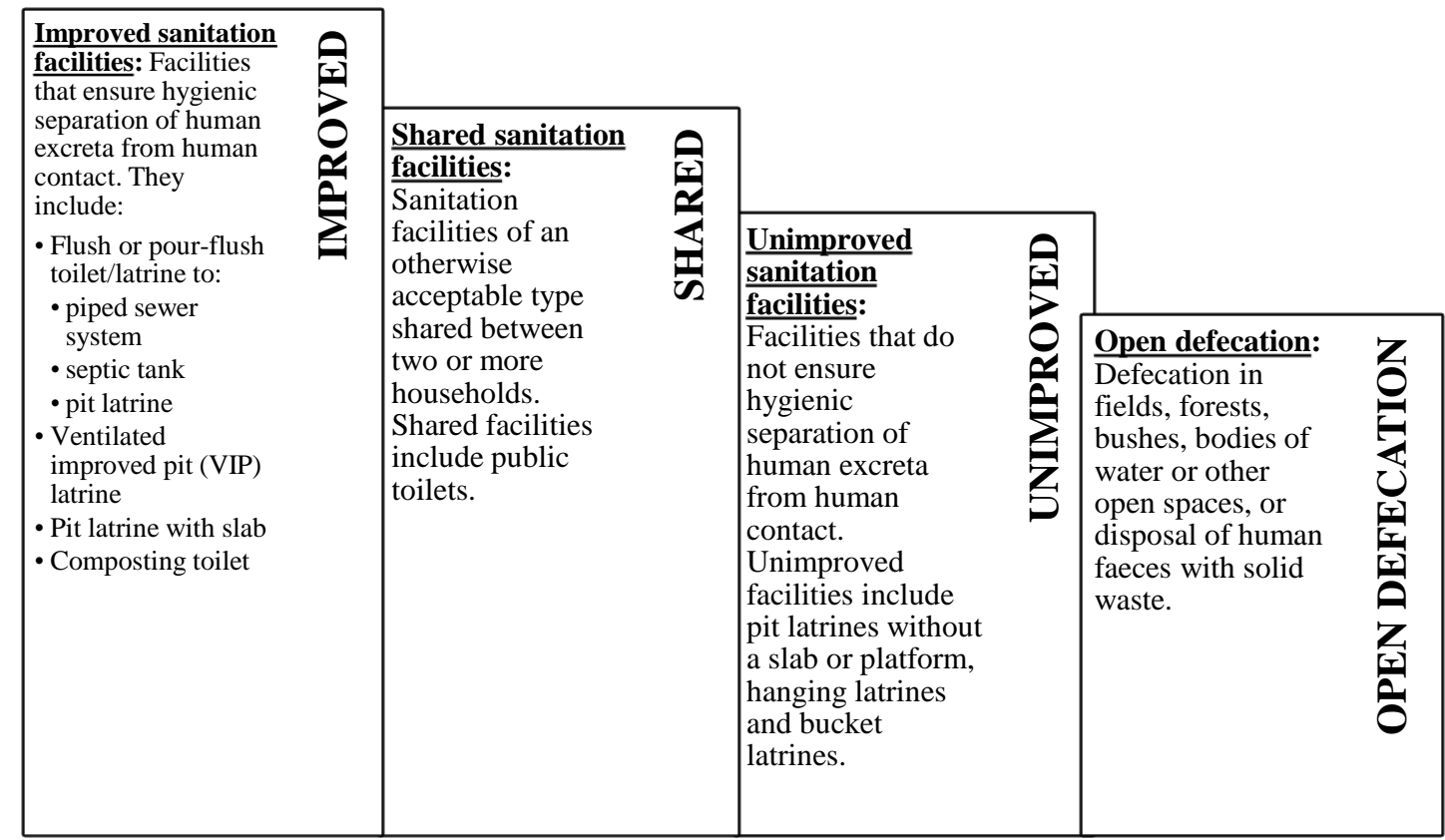

Note: Shared or public facilities are not considered as improved.

Source: Adapted from WHO/UNICEF JMP (2008: 8).

\section{Figure 1. Classification of sanitation facility: The Sanitation Ladder}

Figure 1 shows a more detailed classification of sanitation facilities, where the four categories of sanitation facility (from best to worst) are improved, shared, unimproved, and open defecation (no facility at all). For this study, the four categories were reduced to two categories where open defecation, shared facility and unimproved facility were grouped as unimproved facility (coded 0 ) while improved facility stands on its own (coded 1). There were two grounds behind this grouping. First, the small sample size of the 2011 Indonesia MICS data limits the power of each categories of explanatory variables. Second, quality of shared sanitation varies (Mazeau, Reed, Sansom, \& Scott, 2014). Therefore, the last reason, shared sanitation still poses increased odds of diarrhoea compared to individual household sanitation (Fuller, Clasen, Heijnen, \& Eisenberg, 2014; Heijnen et al., 2014).

The explanatory variables - comprising three main groups (spatial, environmental, socio-demographic, and economic variables) - were carefully chosen by examination of statistical significance (i.e. at the 5\% level of significance) and existing literature (Hosmer, Lemeshow, \& Sturdivant, 2013). Those variables are explained in more details in the subsequent section.

\footnotetext{
${ }^{1}$ Kaimana Regency was chosen as the referent category due to its lowest share of households with access to improved sanitation facility. It is worth noting that changing the referent category of
}

Previous studies have shown that there are geographic disparities of access to improved sanitation facilities across provinces and between urban areas and rural areas (Ghosh \& Cairncross, 2014; Prasetyoputra \& Irianti, 2013; Pullan, Freeman, Gething, \& Brooker, 2014; Rheingans, Anderson, Luyendijk, \& Cumming, 2014). Hence, the spatial variables included in this study were: district (1, Merauke Regency; 2, Jayawijaya Regency; 3, Biak Numfor Regency; 4, Kaimana ${ }^{l}$ Regency [referent category]; 5, Manokwari Regency; 6, Sorong Regency) and place of residence (1, urban area [referent category]; 2, rural area).

Sufficient quantity of domestic water supply is needed for hygiene purposes as lack of which can lead to poor hygiene practices (Howard \& Bartram, 2003). The 2011 MICS, however, did not collect data on water quantity at the household level. Hence, type of water source and location of water source were used as proxies for water quantity. Previous studies have demonstrated that households who sourced their drinking water from an improved source are more likely to use improved sanitation when defecation (Hunter, MacDonald, \& Carter, 2010; Prasetyoputra \& Irianti, 2013). Another study by Irianti, Saputro, Sasimartoyo, Prasetyoputra, and Kurniasih (2014) found that households that rely on improved water sources use higher quantities of water

District would not lead to changes in the coefficients of other covariates. 
for all household purposes than those that rely on unimproved water sources. Moreover, the same study demonstrated that households that obtain their water from sources located not in their premises use less water, on average, compared to those that have water sources close by, implying a time cost in collecting water (Irianti, et al., 2014).

For the reasons above, the environmental factors in this study were main water source for other household purposes ( 0 , unimproved; 1 , improved) and location of that water source $(0$, water source located on premises; 1 , water source located elsewhere). To prevent perfect collinearity, those two variables were combined (interaction) resulting in a four category variable (1, improved water + on premise; 2 , unimproved water + on premise; 3 , improved water + located elsewhere; and 4 , unimproved water + located elsewhere).

Demographic factors such as age and household size have been shown to be associated with water and sanitation (Francisco, 2014; Gross \& Günther, 2014; Jenkins \& Cairncross, 2010; Jenkins \& Scott, 2007; Wright \& Gundry, 2009). In this study, variables intended to represent demographic characteristics of the households were household size (number of household members of any age - in discrete form), age of household head (in years), squared age of household head, ethnicity of household head (1, Papuan [referent category]; 2, Javanese; 3, other ethnicity), and household head is a migrant ( 0 , no [referent category]; 1 , yes).

Socio-economic position (SEP) of household plays an important role in household's ability to achieve better health status. Poverty hinders access to better sanitation, while wealth enables it. The higher the affluence of the household, the more likely it uses improved sanitation facility (Adams, Boateng, \& Amoyaw, 2015; Blakely, et al., 2005; Prasetyoputra \& Irianti, 2013). As such, in this study, education of household head and wealth of household were used as indicators of SEP.

The first indicator of SEP in this study is highest educational attainment of household head (1, no formal education [referent category]; 2, primary school; 3, junior high school; 4, senior high school or higher). Education has been widely used as an indicator of SES (Oakes \& Kaufman, 2006). It has been demonstrated

\footnotetext{
${ }^{2}$ Assets comprise radio, television, fridge, cable television, watch, mobile phone, motorcycle, land, livestock, mosquito bed net, and bicycle/cart.
}

that households headed by a more educated person have higher odds of accessing improved sanitation facility (Prasetyoputra \& Irianti, 2013). The second indicator of SES is wealth index in the form of standardised scores. This indicator has been commonly used in previous studies (Blakely, et al., 2005; Howe et al., 2012; Vyas \& Kumaranayake, 2006). The details on the construction of wealth index can be seen in the Econometric Analyses section.

The data analysis consists of two parts, first, construction of a new set of wealth index scores, and second, regression analysis. However, prior to the aforementioned analyses, a list wise deletion was performed to handle the missing values (Dong \& Peng, 2013). This method was chosen instead of more sophisticated methods (for instance, multiple imputation of missing values (see Royston (2004)) due to presumably insignificant bias emanating from the small number of missing values in the 2011 Indonesia MICS datasets.

A new set of wealth index scores was calculated because the existing wealth index scores in MICS already included sanitation facility as one of the components (Statistics Indonesia, 2013a, 2013b) and therefore such variable must be excluded to prevent redundancy. The index was constructed from 19 variables categorised into ownership of assets ${ }^{2}$ and housing variables ${ }^{3}$. The standardised scores were obtained by employing polychoric principal component analysis (PCA) ${ }^{4}$ which can take into account ordinal form of variables (Kolenikov \& Angeles, 2004, 2009). The wealth index had a polychoric correlation coefficient $(\rho)$ of 0.1697 and the first component explained 45.73 per cent of the variance.

The outcome variable is in binary form, hence, due to several violations of using OLS method on a limited dependent variable (Hill, Griffiths, \& Lim, 2011), the choice of statistical model comes down to probit regression model (PRM) or logistic regression model (LRM). In this study, the former is preferred over the latter for three reasons. First, when the occurrence of the outcome is rare, the odds ratio (OR) from the LRM approximates risk. However, as the outcome gets more common, the OR deviates from risk resulting of an overestimation of the association between the explanatory variable and the outcome variable (Sainani,

\footnotetext{
${ }^{3}$ Housing variables are tenure, number of rooms used for sleeping, occupancy density, material of wall, material of floor, material of roof, type of cooking fuel, and access to electricity.

${ }^{4}$ Polychoric PCA was executed using the 'POLYCHORICPCA' command in STATA (Kolenikov \& Angeles, 2004).
} 
2011). In this case, almost half of the household reported using improved sanitation facility for defecation. Second, a constant change of in the odds does not correspond to a constant change in the probability, and hence the probabilities from probit regression are more meaningful to interpret (Long \& Freese, 2014). Third, PRM has been widely used in global literature (see Francisco (2014); Gross and Günther (2014)).

The probit model specifies the conditional probability as

$$
P=\phi\left(x^{\prime} \beta\right)=\int_{-\infty}^{x^{\prime} \beta} \phi(z) d z, \quad \text { (Eq. 1) }
$$

where $\phi($.$) is the standard normal cumulative$ distribution function (cdf), with derivative $\phi(\mathrm{z})=$ $\left(\frac{1}{\sqrt{2 \pi}}\right) \exp \left(\frac{-z^{2}}{2}\right)$, which is the standard normal density function (Cameron \& Trivedi, 2005). The probit MLE first-order conditions are that

$$
\sum_{i=1}^{N} w_{i}\left(y_{i}-\phi\left(x_{i}^{\prime} \beta\right)\right) x_{i}=0, \quad \text { (Eq. 2) }
$$

where, unlike the logit model, the weight $\mathrm{w}_{\mathrm{i}}=$ $\phi\left(\mathrm{x}_{\mathrm{i}}^{\prime}\right) /\left[\phi\left(\mathrm{x}_{\mathrm{i}}^{\prime} \beta\right)\left(1-\phi\left(\mathrm{x}_{\mathrm{i}}^{\prime} \beta\right)\right)\right]$ varies across observations (Cameron \& Trivedi, 2005). Therefore, the PRM of access to improved sanitation can be specified as

$$
\begin{aligned}
\mathrm{p}=\mathrm{P} \text { [IMPSANIT } & \\
& \leq \beta_{1}+\beta_{2} \text { EXPVAR } 1 \\
& \left.+\delta_{1} \text { DUMMY1 }+\cdots\right] \\
& =\phi\left(\beta_{1}+\beta_{2}\right. \text { EXPVAR1 } \\
& \left.+\delta_{1} \text { DUMMY } 1+\cdots\right)
\end{aligned}
$$

where IMPSANIT denotes access to improved sanitation, EXPVAR denotes continuous/discrete explanatory variables and DUMMY denotes dummy explanatory variables.

The first stage of the regression analyses was the bivariate regression of each potential explanatory variable. Variables that were statistically significant or have substantial importance albeit insignificant were included in the final multivariate PRM. Statistical significance was evaluated at $\mathrm{p}<0.05$, but additional markers were added to variables that are significant at $p<0.001$. Moreover, survey design for the dataset was declared before the regressions (Kreuter \& Valliant,
2007). Also, those variables were examined for severe collinearity (see Hill et al. (2011) for the impact of severe collinearity), which is when the value of variance inflating factor (VIF) exceeds 10 (Chatterjee \& Hadi, 2012; Gujarati, 2004). The VIFs were examine using unweighted regression.

The coefficients from PRM cannot be directly interpreted. As such, marginal average effects (AME) were computed using 'MARGINS' command (Long \& Freese, 2014) along with their 95 per cent confidence intervals $(95 \% \mathrm{CI})$ to obtain the probabilities based on the explanatory variables. All of the analyses were performed using Intercooled STATA version 13.1 (StataCorp, 2013).

\section{FACTORS CORRELATES OF ACCESS TO IMPROVED SANITATION}

Table 1 shows simple summary statistics and VIF of variables selected for the final model. The table shows that an estimated 52.70 per cent (95\% CI: 48.87, 56.53) of households have access to improved sanitation facilities. Also, the mean VIF of the final model was 3.78 , and none of the explanatory variables had VIF of over 10 .

Regarding district of residence, the majority of sampled households live in Manokwari Regency (28.41\%) while the least households live in Kaimana Regency (7.65\%). As for the place of residence, two-thirds of the sample households live in the rural areas ${ }^{5}$ while the rest lives in urban areas.

The only environmental variable was an interaction between water source for all household purposes and location of that water source. It was estimated that households predominantly use improved water located on their premises $(53.39 \%)$, followed by use of unimproved water located outside (20.69\%), unimproved on-premise water source $(14.01 \%)$, and improved water located elsewhere (11.91\%).

There were four demographic factors used in the analysis, namely number of persons in the household (household size), the average age of household head, ethnicity of household head, and migration status of the household head. The sampled household has an average of four members. Regarding age, the average age of household head is 43 years. As for ethnicity, the majority of head of household are Papuan (49.26\%), followed by Javanese (29.68\%), and other ethnicities

\footnotetext{
5 This may cause overrepresentation of rural households. The authors thank anonymous reviewer for pointing this out.
} 
(21.06\%). Lastly, with regard to migration, less than half of head of household are migrant (45.18\%).

The socio-economic factors in this study were education of household head and household wealth. With regard to education, more than two fifths of household heads are junior high school graduates (42.29\%), followed by primary school graduates (33.23), and senior high school graduates (14.41\%). While one tenth of household heads has no formal education at all. Wealth index scores used as indicator of household wealth is averaged at 0.20 .

Table 1. Descriptive statistics for selected variables and their VIFs

\begin{tabular}{|c|c|c|c|}
\hline$N=\mathbf{5 5 0 0}$ & Categories & $\begin{array}{c}\text { Weighted } \\
\text { mean/per cent }\end{array}$ & VIF* \\
\hline \multicolumn{4}{|l|}{ Outcome variable } \\
\hline \multirow[t]{2}{*}{ Access to improved sanitation facility } & No (Ref.) & 47.30 & N.A. \\
\hline & Yes & 52.70 & N.A. \\
\hline \multicolumn{4}{|l|}{ Spatial variables } \\
\hline \multirow{6}{*}{ District } & Kaimana (Ref.) & 7.65 & N.A. \\
\hline & Jayawijaya & 14.38 & 2.46 \\
\hline & Biak Numfor & 14.58 & 2.16 \\
\hline & Merauke & 22.16 & 2.16 \\
\hline & Manokwari & 28.41 & 2.04 \\
\hline & Sorong & 12.82 & 2.38 \\
\hline \multirow[t]{2}{*}{ Place of residence } & Urban area (Ref.) & 32.28 & N.A. \\
\hline & Rural area & 67.72 & 4.71 \\
\hline \multicolumn{4}{|l|}{ Environmental variables } \\
\hline \multirow[t]{4}{*}{ Interaction variable } & $\begin{array}{l}\text { Improved water }+ \text { located on premise } \\
\text { (Ref.) }\end{array}$ & 53.39 & N.A. \\
\hline & $\begin{array}{l}\text { Unimproved water }+ \text { located on } \\
\text { premise }\end{array}$ & 14.01 & 1.31 \\
\hline & Improved water + located elsewhere & 11.91 & 1.33 \\
\hline & $\begin{array}{l}\text { Unimproved water + located } \\
\text { elsewhere }\end{array}$ & 20.69 & 2.33 \\
\hline \multicolumn{4}{|l|}{ Demographic factors } \\
\hline Household size (in persons) & N.A. & 4.17 & 5.10 \\
\hline Age of household head (in years) & N.A. & 43.41 & 8.92 \\
\hline \multirow[t]{3}{*}{ Ethnicity of household head } & Papuan (Ref.) & 49.26 & N.A. \\
\hline & Javanese & 29.68 & 6.36 \\
\hline & Other ethnicity & 21.06 & 5.08 \\
\hline \multirow[t]{2}{*}{ Household head is a migrant } & No (Ref.) & 54.82 & N.A. \\
\hline & Yes & 45.18 & 8.57 \\
\hline \multicolumn{4}{|l|}{ Socio-Economic Position } \\
\hline \multirow[t]{4}{*}{ Highest education of household head } & No formal education (Ref.) & 10.06 & N.A. \\
\hline & Primary school & 33.23 & 3.46 \\
\hline & Junior high school & 42.29 & 4.34 \\
\hline & Senior high school or higher & 14.41 & 2.17 \\
\hline Wealth index score & N.A. & 0.20 & 3.68 \\
\hline
\end{tabular}

Notes: $\quad$ Ref.: Referent category; N.A.: Not applicable; * From unweighted multivariate probit regression.

Source: Author's calculation of the 2011 Indonesia MICS 


\section{Spatial Correlates}

The final model was highly statistically significant $\left(F_{(18,199)}=41.20 ; \mathrm{p}<0.001\right)$. Table 2 presents the probit coefficients from the bivariate and multivariate probit regressions along with their 95 per cent CI.

The simple relationship between district and access to improved sanitation facility was statistically significant $(\mathrm{p}<0.001)$ with varying magnitude and direction of the coefficients. In the multivariate model, district was still statistically significant $(\mathrm{p}<0.001)$. Moreover, the simple association between being located in a rural area (compared to living in urban area) and access to improved sanitation facility was negative and statistically significant $(p<0.001)$. The direction of this relationship, however, changed into a positive one and still statistically significant $(\mathrm{p}<0.001)$.

\section{Environmental Correlates}

The simple correlation between type of water source for all household purpose and location and access to improved sanitation facility was statistically significant $(\mathrm{p}<0.001)$ with all categories statistically different from the referent category (water source is improved and located on premise). In the multivariate model, the association was still statistically significant $(\mathrm{p}<0.001)$. Compared to referent households, households who sourced their water from an improved source but located elsewhere $(p=0.002)$ and households who sourced their water from an unimproved source located elsewhere $(p<0.001)$ were negatively associated with access to improved sanitation facility. However, access to improved sanitation for households who sourced their water from an unimproved water located on premise was not statistically different from referent households $(p=0.235)$.

\section{Demographic Correlates}

The demographic factors in this study were household size, age of household head, ethnicity of household head, and migrant status of household head. Household size was found to be statistically significant $(p<0.001)$ and the simple relationship with access to improved sanitation facility was positive. This was also true for the adjusted association ( $p<0.001)$. Likewise, age of household head was also found to be statistically significant $(p<0.001)$ and the simple association with access to improved sanitation was positive. This relationship holds in when other covariates were included in the final model $(\mathrm{p}<0.001)$.

Moreover, ethnicity of household head was found to be statistically associated with differences in access to improved sanitation facility in the simple regression $(\mathrm{p}<$ 0.001 ), but not in the final multivariate model ( $\mathrm{p}=$ 0.5692 ). Lastly, households headed by a migrant were found to be positively and significantly correlated $(\mathrm{p}<$ 0.001 ) with access to improved sanitation facility. This correlation, however, became statistically insignificant when other covariates were taken into account $(\mathrm{p}=$ 0.9594).

\section{Socio-Economic Correlates}

The socio-economic factors in this study were highest educational attainment of household head and household wealth. In the simple regression, compared to households headed by a non-educated person, households headed by a primary school graduate $(\mathrm{p}<$ 0.001 ), households headed by junior high school graduate $(\mathrm{p}<0.001)$, and households headed by a senior high school graduate or higher were found to be positively associated with access to improved sanitation facility. There was also a significant and positive gradient in the probability of access to improved sanitation facility. In the final multivariate model, the positive association and gradient remained statistically significant $(\mathrm{p}<0.001)$. Lastly, increases in wealth index score was found to be statistically related $(\mathrm{p}<0.001)$ to access to improved sanitation facility. This relationship holds $(p<0.001)$ when other covariates were included in the final multivariate model. 
Table 2. Coefficients from Simple and Multivariate Probit Regressions

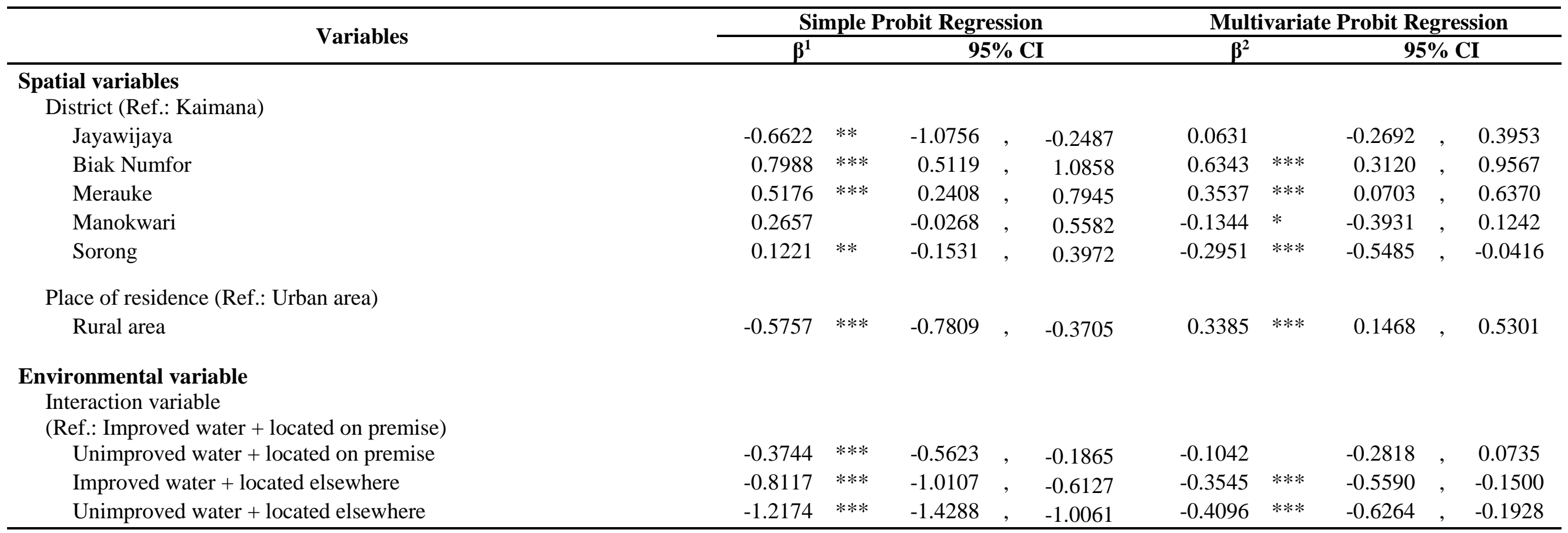

Notes : $\quad$ Ref.: Referent category; N.A.: Not applicable; $* \leq 0.05 ; * * p \leq 0.01 ; * * * p \leq 0.001 ;{ }^{1}$ crude coefficients; ${ }^{2}$ adjusted coefficients.

Source: $\quad$ Author's calculation of the 2011 Indonesia MICS 
Table 2. (continued)

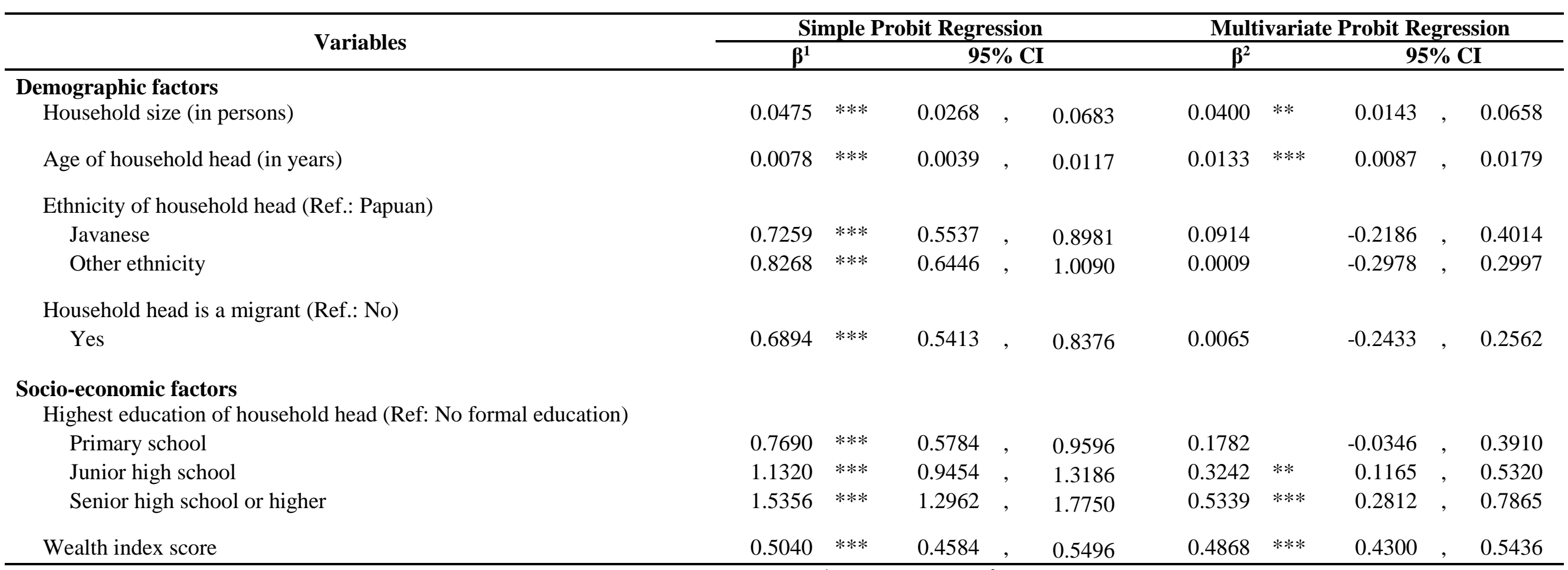

\begin{tabular}{ll}
\hline Notes : & Ref.: Referent category; N.A.: Not applicable; $* \leq 0.05 ;{ }^{* *} p \leq 0.01 ; * * * \leq 0.001 ;{ }^{*}$ crude coefficients; ${ }^{2}$ adjusted coefficients. \\
Source : & Author's calculation of the 2011 Indonesia MICS
\end{tabular} 


\section{SPATIAL INEQUALITIES IN ACCESS TO IMPROVED SANITATION}

This study has identified the environmental, demographic, and socio-economic correlates of use of improved latrine at household level. Seven of the nine explanatory variables were found to be statistically associated with households' access to improved sanitation facility. Figure 2 presents the AMEs (and 95\% CI) of variables significant at the 5 per cent level of significance. A category is significant if the line of the 95 per cent CIs does not intersect the zero line.

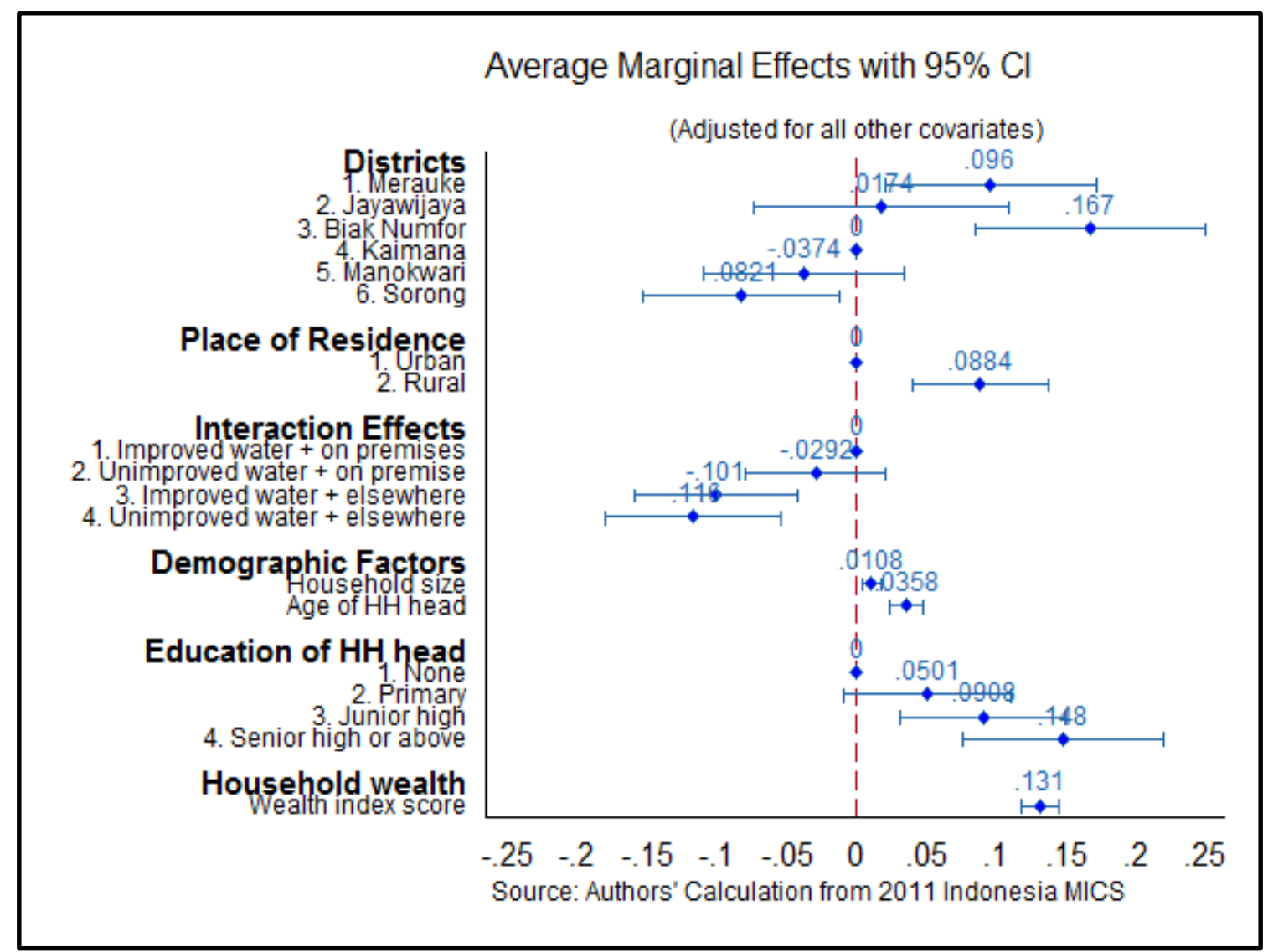

Note: Ethnicity of household head and migrantship of household head were omitted from the graph as they were not statistically significant.

Figure 2. Average Marginal Effects from the Final Regression Model

This study found indication of spatial disparities both across districts and between urban and rural areas. Access of improved sanitation facility in three of five districts was found to be significantly different from the referent district, Kaimana Regency. The AMEs ranged from 9.60 to 17.80 per cent. This indicates spatial disparities of access to improved sanitation facilities. This is consistent with extant scholarship that demonstrated evidence of geographical disparities of access to improved sanitation facility in Indonesia (Irianti, et al., 2014; Prasetyoputra \& Irianti, 2013), India (Ghosh \& Cairncross, 2014), and Ghana (Adams, et al., 2015).

As for place of residence, households living in rural areas have 8.84 (95\% CI: 3.98, 13.69) per cent higher probability of having access to improved sanitation facility than their urban counterparts (despite being otherwise in the simple regression). This is different from the findings of existing studies revealing urban advantage in access to improved sanitation (Ghosh \& Cairncross, 2014; National Research Council, 2003; Prasetyoputra \& Irianti, 2013). Moreover, Adams, et al. (2015) also found conflicting evidence. They found that the less developed the area is, the less the likelihood of a household living in it in accessing improved sanitation facility. In this case, households living in country sides, towns, and small cities were found to have lower likelihood in accessing improved latrines. One possible reason for this anomaly of direction the AME of rural area is that the sample is only representative for Papua and West Papua. Another is that the urban area needs to be disaggregated into poor urban and affluent urban. 
Last reason is that factors other than place of residence explain access to improved sanitation more.

\section{ENVIRONMENTAL CORRELATES OF ACCESS TO IMPROVED SANITATION}

The referent category for the interaction between water source of all household purposes and its location was improved water located on premise. Households with unimproved water located on premise were found to have 2.92 per cent $(95 \%$ CI: $-7.93,2.08)$ lower probability of having access to improved sanitation facility than referent households. This association, however, was not statistically significant. Moreover, households with improved water located elsewhere were found to have 10.10 per cent less $(95 \%$ CI: 4.20 , 15.90) likelihood of having access to improved sanitation facility than referent households. Lastly, households with unimproved water located elsewhere were found to have 11.6 per cent lower (95\% CI: 5.36, 17.90) probability of having access to improved sanitation facility than the referent category.

This confirms previous studies that find a positive relationship between improved drinking water source and probability of having access to improved sanitation facility (Adams, et al., 2015; Jenkins \& Cairncross, 2010; Prasetyoputra \& Irianti, 2013). Moreover, the study by Adams, et al. (2015) also found a negative relationship between time needed to reach water source and access to improved sanitation facility. The farther the distance of the water source, the less water one can fetch, and hence the lower the probability of using improved sanitation facility for defecation (Prasetyoputra \& Irianti, 2013).

\section{DEMOGRAPHIC CORRELATES OF ACCESS TO IMPROVED SANITATION}

The first of the two demographic factors was household size. For every 10 person increase in number of household members, the probability of having access to improved sanitation facility increases by 1.08 per cent (95\% CI: $0.38,1.77)$. This is different from the finding of the research by Adams, et al. (2015) where number of household members was found to be negatively related with access to improved sanitation facility. This relationship, however, was not statistically significant when other factors were included in the final model.

The other demographic factor was age of household head. For every 10-year increase in the age of head of household, the probability of having access to improved sanitation facility increases by 3.58 per cent (95\% CI: $2.36,4.81)$. This is consistent with the study done by Gross and Günther (2014) where they found a positive and statistically significant relationship between age of household head and probability of latrine ownership.

\section{SOCIO-ECONOMIC INEQUALITIES ACCESS TO IMPROVED SANITATION}

IN

The findings of this study revealed that households headed by a person who has primary education have 5.01 per cent $(95 \%$ CI: $-0.97,10.99)$ higher probability compared to referent households. However, this association was not statistically significant. Moreover, households headed by a person who has junior high education have 9.08 per cent (95\% CI: 3.19, 14.98) higher probability compared to referent households. Furthermore, households headed by a person who has senior high education or higher have 14.80 per cent (95\% CI: $7.63,21.94)$ higher probability compared to referent households. This shows an increasing likelihood of accessing improved sanitation facility as educational attainment of household head gets higher. This is consistent with studies by Prasetyoputra and Irianti (2013) and Tiwari and Nayak (2013) that found positive relationship between education and access to improved sanitation facility. One possible explanation for this is that people with higher educational status have more knowledge of health risks associated with inadequate sanitation (Adams, et al., 2015; Kirigia \& Kainyu, 2000).

Furthermore, household wealth was found to be positively associated with ownership of improved sanitation facility. For every 1 unit increase in wealth index score, the probability of having access to improved sanitation facility increases by 13.10 per cent (95\% CI: 11.79, 14.43). 


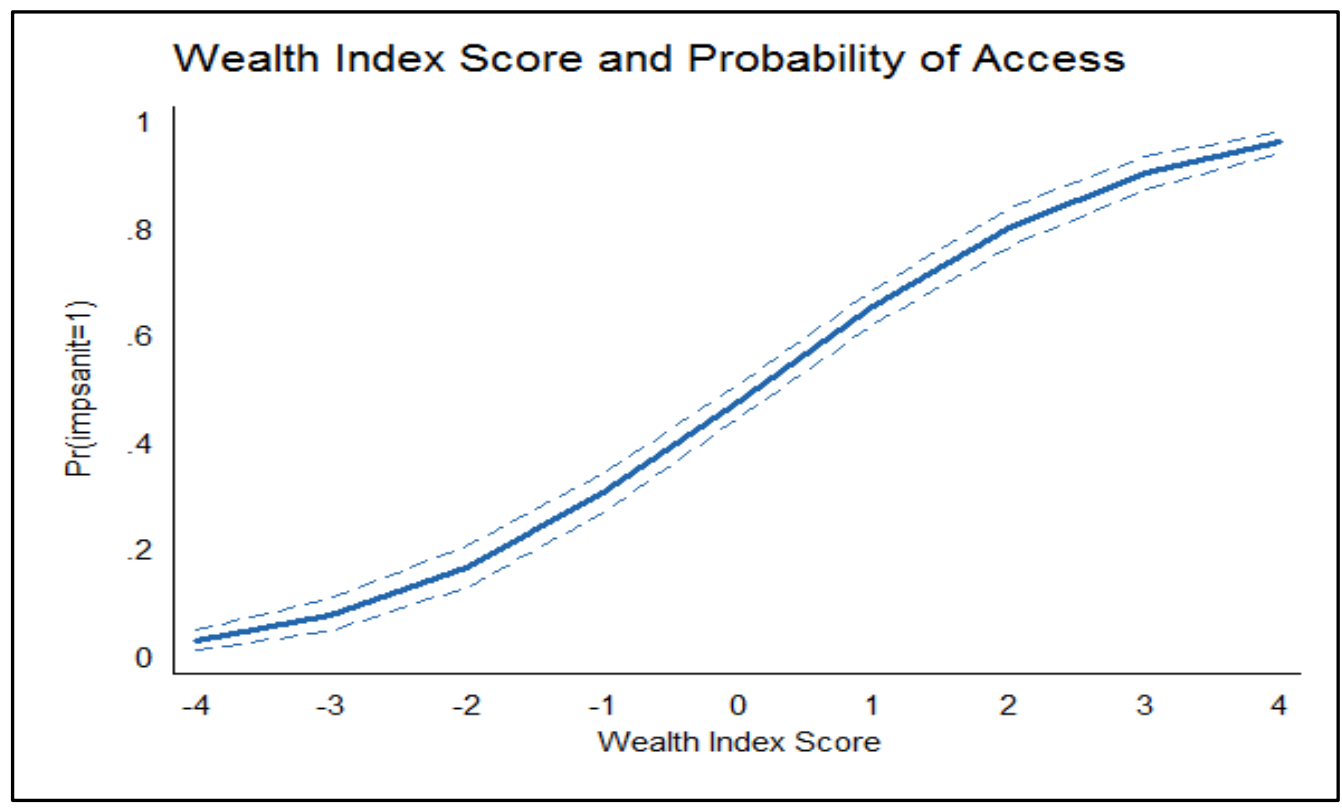

Note: Adjusted for all other covariates.

Figure 3. Household Wealth and Access to Improved Sanitation

Figure 3 shows the relationship between units of wealth index score and probability of having access to improved sanitation facility depicting a clearer positive relationship between those variables. This finding confirms that of existing scholarship that found positive relationship between household wealth and ownership of improved latrine in Indonesia (Irianti, et al., 2014; Prasetyoputra \& Irianti, 2013), Ghana (Adams, et al., 2015), Benin (Gross \& Günther, 2014), and in many countries (Blakely, et al., 2005).

\section{POLICY IMPLICATIONS}

Based on a recent national survey in 2013, Papua Province had the highest burden of diarrhoea. The period prevalence rate in that province was $14.3 \%$, which is twofold of the national rate (NIHRD, 2013). Conversely, the period prevalence rate in West Papua Province is $5.2 \%$ which is lower than the national rate (NIHRD, 2013). Nonetheless, these burden of diarrhoea are preventable and increasing access to adequate sanitation facilities is one way to reduce it.

Educational status of household head was found to be positively associated with probability of accessing improved sanitation facility. Hence, improving educational attainment of the people of West Papua and Papua Provinces could, in the long run, improve people's access to improved sanitation facilities. Furthermore, wealth status of households was also found to be positively correlated with probability of having improved latrines. As such, increasing employment opportunities also can be done to improve people's economic livelihood such that they will be able to afford better sanitation facilities. These possible pathways of improving access implies that a concerted effort from many stakeholders is needed

\section{STUDY LIMITATIONS}

There are several limitations to this study. First, there may still be unobserved confounding due to potential confounders not collected by the survey. Second, there is a possibility of overrepresentation of households living in rural areas. However, the effect of this cannot be determined in this study. Third, the data are representative only for Papua Province and West Papua Province, not Indonesia. These limitations could not be corrected for in this paper. Future studies using longitudinal data and experimental designs to examine changes in demographic characteristics and improved sanitation facility ownership are recommended.

\section{CONCLUSION}

To the best of the authors' knowledge, this is the first study that analysed the 2011 Indonesia MICS data to assess the demographic and socio-economic correlates of access to improved sanitation facility in Papua Province and West Papua Province. The results suggest that the significant demographic correlates were household size and age of household head. While the significant socio-economic correlates were highest education attained by head of household and household 
wealth. The findings also suggest spatial disparities across districts and in terms of place of residence showing unusual rural advantage. Furthermore, type of water source for other household purposes and location of that water source also determines the probability of access to improved sanitation facility. These findings should be taken into account in the policy making process related to Papua and West Papua Province by either the national or local government.

\section{Acknowledgements}

The authors wish to acknowledge The United Nations Children's Fund (UNICEF) for providing the permission to analyse the 2011 Indonesia MICS datasets. The authors' gratitude also goes to two anonymous reviewers for the constructive comments on the earlier version of this paper and Tri Prasetyo Sasimartoyo, M.Sc., Ph.D for his guidance on the statistical analyses. This study received no external funding and the authors declare no conflict of interest.

\section{REFERENCES}

Adams, E. A., Boateng, G. O., \& Amoyaw, J. A. 2015. Socioeconomic and Demographic Predictors of Potable Water and Sanitation Access in Ghana. Social Indicators Research, 1-15. doi: 10.1007/s11205-015-0912-y

Bain, R., Cronk, R., Hossain, R., Bonjour, S., Onda, K., Wright, J., . . Bartram, J. 2014. Global assessment of exposure to faecal contamination through drinking water based on a systematic review. Tropical Medicine \& International Health, 19(8), 917-927. doi: 10.1111/tmi.12334

Blakely, T., Hales, S., Kieft, C., Wilson, N., \& Woodward, A. 2005. The global distribution of risk factors by poverty level. Bulletin of the World Health Organization, 83(2), 118-126. doi: 10.1590/S0042-96862005000200012.

Booth, A. 2004. Africa in Asia? the development challenges facing Eastern Indonesia and East Timor. Oxford Development Studies, 32(1), 19-35. doi: 10.1080/1360081042000184101

Cameron, A. C., \& Trivedi, P. K. 2005. Microeconometrics: methods and applications. New York, NY: Cambridge University Press.

Chatterjee, S., \& Hadi, A. S. 2012. Regression Analysis By Example (5th ed.). Hoboken, New Jersey: John Wiley \& Sons, Inc.

Dong, Y., \& Peng, C.-Y. J. 2013. Principled missing data methods for researchers. SpringerPlus, 2(1), 222. doi: 10.1186/2193-1801-2-222
Francisco, J. P. S. 2014. Why households buy bottled water: a survey of household perceptions in the Philippines. International Journal of Consumer Studies, 38(1), 98-103. doi: 10.1111/ijcs.12069

Freeman, M. C., Stocks, M. E., Cumming, O., Jeandron, A., Higgins, J. P. T., Wolf, J., . . . Curtis, V. 2014. Systematic review: Hygiene and health: systematic review of handwashing practices worldwide and update of health effects. Tropical Medicine \& International Health, 19(8), 906-916. doi: 10.1111/tmi.12339

Fuller, J. A., Clasen, T., Heijnen, M., \& Eisenberg, J. N. S. 2014. Shared Sanitation and the Prevalence of Diarrhea in Young Children: Evidence from 51 Countries, 2001-2011. The American Journal of Tropical Medicine and Hygiene, 91(1), 173-180. doi: 10.4269/ajtmh.13-0503

Fuller, J. A., Westphal, J. A., Kenney, B., \& Eisenberg, J. N. S. 2015. The joint effects of water and sanitation on diarrhoeal disease: a multicountry analysis of the Demographic and Health Surveys. Tropical Medicine \& International Health, 20(3), 284-292. doi: $10.1111 /$ tmi. 12441

Ghosh, A., \& Cairncross, S. 2014. The uneven progress of sanitation in India Journal of Water, Sanitation and Hygiene for Development, 4(1), 15-22. doi: 10.2166/washdev.2013.185

Gleick, P. H. 1998. The human right to water. Water Policy, 1(5), 487-503. doi: 10.1016/S13667017(99)00008-2

Government of Indonesia. 2014. Presidential Regulation of the Republic of Indonesia Number 185 of 2014 on the Acceleration of Drinking-Water and Sanitation Supply. Jakarta: Government of Indonesia, Republic of Indonesia Retrieved from http://stbmindonesia.org/files/PERPRES\%20Nomor\%20185 \%20Tahun\%202014.pdf.

Gross, E., \& Günther, I. 2014. Why do households invest in sanitation in rural Benin: Health, wealth, or prestige? Water Resources Research, 50(10), 83148329. doi: 10.1002/2014wr015899

Gujarati, D. N. 2004. Basic Econometrics (4th ed.). New York: The McGraw-Hill Companies.

Haryanto, B., \& Sutomo, S. 2012. Improving access to adequate water and basic sanitation services in Indonesia. 27(4), 159-162. doi: 10.1515/reveh2012-0022

Heijnen, M., Cumming, O., Peletz, R., Chan, G. K.-S., Brown, J., Baker, K., \& Clasen, T. 2014. Shared Sanitation versus Individual Household Latrines: A Systematic Review of Health Outcomes. PLoS ONE, 9(4), e93300. doi: 10.1371/journal.pone.0093300 
Hill, H., Resosudarmo, B. P., \& Vidyattama, Y. 2008. Indonesia's changing economic geography. Bulletin of Indonesian Economic Studies, 44(3), 407-435. doi: 10.1080/00074910802395344

Hill, R. C., Griffiths, W. E., \& Lim, G. C. 2011. Principles of Econometrics (4th ed.). Hoboken: John Wiley \& Sons, Inc.

Hosmer, D. W., Lemeshow, S., \& Sturdivant, R. X. 2013. Applied Logistic Regression (4th ed.). Hoboken, New Jersey: John Wiley \& Sons, Inc.

Howard, G., \& Bartram, J. 2003. Domestic Water Quantity, Service Level and Health. Geneva: World Health Organization Retrieved from http://www.who.int/water_sanitation_health/disea ses/wsh0302/en/index.html.

Howe, L. D., Galobardes, B., Matijasevich, A., Gordon, D., Johnston, D., Onwujekwe, O., Hargreaves, J. R. 2012. Measuring socio-economic position for epidemiological studies in low- and middle-income countries: a methods of measurement in epidemiology paper. International Journal of Epidemiology, 41(3), 871-886. doi: 10.1093/ije/dys037

Hunter, P. R., MacDonald, A. M., \& Carter, R. C. 2010. Water Supply and Health. PLoS Med, 7(11), e1000361. doi: 10.1371/journal.pmed.1000361

Irianti, S., Saputro, F. E., Sasimartoyo, T. P., Prasetyoputra, P., \& Kurniasih, E. 2014. A Review of Access, Safety, and Use of Drinking-Water from Various Sources in Indonesia. Jakarta: National Institute of Health Research and Development, Ministry of Health, Republic of Indonesia.

Jenkins, M. W., \& Cairncross, S. 2010. Modelling latrine diffusion in Benin: towards a community typology of demand for improved sanitation in developing countries. Journal of Water and Health, 8(1), 166183. doi: 10.2166/wh.2009.111

Jenkins, M. W., \&Scott, B. 2007. Behavioral indicators of household decision-making and demand for sanitation and potential gains from social marketing in Ghana. Social Science \& Medicine, 64, 2427-2442. doi: 10.1016/j.socscimed.2007.03.010

Kirigia, J. M., \& Kainyu, L. 2000. Predictors of toilet ownership in South Africa. East African Medical Journal, 77(12), 667-672. Retrieved from http://www.ajol.info/index.php/eamj/article/view/ $46767 / 33157$

Kolenikov, S., \& Angeles, G. 2004. The use of discrete data in PCA: Theory, simulations, and applications to socioeconomic indices. Carolina Population Center Working Paper No. 04-85. Retrieved from http://www.cpc.unc.edu/measure/publications/wp04-85/at_download/document
Kolenikov, S., \& Angeles, G. 2009. Socioeconomic status measurement with discrete proxy variables: is principal component analysis a reliable answer? Review of Income and Wealth, 55(1), 128-165. doi: 10.1111/j.1475-4991.2008.00309.x

Kreuter, F., \& Valliant, R. 2007. A survey on survey statistics: What is done and can be done in Stata. Stata Journal, 7(1), 1-21.

Long, J. S., \& Freese, J. 2014. Regression Models for Categorical Dependent Variables using Stata (3rd ed.). College Station, Texas: Stata Press.

Mara, D., Lane, J., Scott, B., \& Trouba, D. 2010. Sanitation and Health. PLoS Med, 7(11), e1000363. doi: 10.1371/journal.pmed.1000363

Mazeau, A., Reed, B., Sansom, K., \& Scott, R. 2014. Emerging categories of urban shared sanitation. Water and Environment Journal, 28(4), 592-608. doi: 10.1111/wej.12075

National Research Council. 2003. Cities Transformed: Demographic Change and Its Implications in the Developing World. Washington, DC: The National Academies Press.

NIHRD. 2013. Baseline Health Research Report, 2013 [Laporan Riset Kesehatan Dasar 2013]. Jakarta: National Institute of Health Research and Development (NIHRD), Ministry of Health Indonesia (MoH), Republic of Indonesia.

Oakes, J. M., \& Kaufman, J. S. (Eds.). (2006). Methods in Social Epidemiology. San Francisco, CA: JosseyBass.

Patunru, A. A. 2015. Access to Safe Drinking Water and Sanitation in Indonesia. Asia \& the Pacific Policy Studies, 2(2), 234-244. doi: 10.1002/app5.81

Prasetyoputra, P., \& Irianti, S. 2013. Access to improved sanitation facilities in Indonesia: An econometric analysis of geographical and socioeconomic disparities. Journal of Applied Sciences in Environmental Sanitation, 8(3), 215-224. Retrieved from http://www.trisanita.org/jases/v08n3y2013.html

Prüss-Ustün, A., Bartram, J., Clasen, T., Colford, J. M., Cumming, O., Curtis, V., .. Cairncross, S. 2014. Burden of disease from inadequate water, sanitation and hygiene in low- and middle-income settings: a retrospective analysis of data from 145 countries. Tropical Medicine \& International Health, 19(8), 894-905. doi: 10.1111/tmi.12329

Pullan, R. L., Freeman, M. C., Gething, P. W., \& Brooker, S. J. 2014. Geographical Inequalities in Use of Improved Drinking Water Supply and Sanitation across Sub-Saharan Africa: Mapping and Spatial Analysis of Cross-sectional Survey Data. PLoS Med, 11(4), e1001626. doi: 10.1371/journal.pmed.1001626 
Rheingans, R., Anderson, J. D., Luyendijk, R., \& Cumming, O. 2014. Measuring disparities in sanitation access: does the measure matter? Tropical Medicine \& International Health, 19(1), 2-13. doi: 10.1111/tmi.12220

Royston, P. 2004. Multiple imputation of missing values. Stata Journal, 4(3), 227-241. Retrieved from http://www.stata-

journal.com/article.html?article=st0067

Rufener, S., Mäusezahl, D., Mosler, H.-J., \& Weingartner, R. 2010. Quality of drinking-water at source and point-of-consumption-drinking cup as a high potential recontamination risk: A field study in Bolivia. Journal of Health, Population and Nutrition, 28(1), 34-41.

Sainani, K. L. 2011. Understanding odds ratios. $P M \& R, 3(3)$, 263-267. doi: 10.1016/j.pmrj.2011.01.009

StataCorp. 2013. Stata Statistical Software: Release 13. College Station, TX: StataCorp LP.

Statistics Indonesia. 2013a. The Selected Districts of Papua Province Multiple Indicator Cluster Survey 2011, Final Report. Jakarta, Indonesia: Statistics Indonesia - Badan Pusat Statistik Retrieved from http://www.childinfo.org/files/MICS4_Indonesia_ Selected_Districts_of_Papua_Province_Final_Rep ort_2011.pdf.

Statistics Indonesia. 2013b. The Selected Districts of West Papua Province Multiple Indicator Cluster Survey 2011, Final Report. Jakarta, Indonesia: Statistics Indonesia - Badan Pusat Statistik Retrieved from http://www.childinfo.org/files/MICS4_Indonesia_ Selected_Districts_of_West_Papua_Province_Fin al_Report_2011.pdf.

Statistics Indonesia. 2014. Indonesia - Multiple Indicator Cluster Survey (MICS) 2011. Jakarta: Statistics Indonesia - Badan Pusat Statistik, Republic of Indonesia Retrieved from http://microdata.bps.go.id/mikrodata/index.php/ca talog/172/related_materials.
The Lancet. 2014. Water and sanitation: addressing inequalities. [Editorial]. The Lancet, 383(9926), 1359. doi: 10.1016/S0140-6736(14)60665-6

Tiwari, R., \& Nayak, S. 2013. Drinking water and sanitation in Uttar Pradesh: A regional analysis. Journal of Rural Development, 32(1), 61-74.

United Nations. 2010. United Nations General Assembly: Resolution 64/292. New York: United Nations Retrieved from http://www.dgvn.de/fileadmin/user_upload/DOK UMENTE/English_Documents/A-Res-64292.pdf.

Vyas, S., \& Kumaranayake, L. 2006. Constructing socioeconomic status indices: how to use principal components analysis. Health Policy and Planning, 21(6), 459-468. doi: 10.1093/heapol/czl029

WHO/UNICEF JMP. 2006. Core Questions on Drinking Water and Sanitation for Household Surveys. Geneva: World Health Organization Retrieved from

http://www.who.int/water_sanitation_health/monit oring/oms_brochure_core_questionsfinal24608.pd

WHO/UNICEF JMP. 2008. Progress on drinking water and sanitation: Special focus on sanitation. Geneva, Switzerland: WHO Press Retrieved from http://www.unicef.org/media/files/Joint_Monitori ng_Report_-_17_July_2008.pdf.

WHO/UNICEF JMP. 2014. Progress on Sanitation and Drinking-Water: 2014 Update. Retrieved from http://www.unwater.org/fileadmin/user_upload/un water_new/docs/jmp.2014_eng.pdf

Wright, J., \& Gundry, S. W. 2009. Household characteristics associated with home water treatment: an analysis of the Egyptian Demographic and Health Survey. Journal of Water and Health, 7(1), 21-29. doi: 10.2166/wh.2009.056 
Jurnal Kependudukan Indonesia | Vol. 10, No. ,1 Juni 2015 | 11-26 